\title{
Pemodelan Geographically Weighted Regression Menggunakan Pembobot Kernel Fixed dan Adaptive pada Kasus Tingkat Pengangguran Terbuka di Indonesia
}

\author{
Mila Rizki Ramadayani ${ }^{1, a)}$, Fariani Hermin Indiyah ${ }^{1, b)}$, Ibnu Hadi ${ }^{1, c)}$ \\ ${ }^{1}$ Program Studi Matematika, Fakultas Matematika dan Ilmu Pengetahuan Alam, Universitas Negeri Jakarta \\ Email: a)milarizki69@gmail.com, ${ }^{\text {b) }}$ farianihermin828@gmail.com, ${ }^{\mathrm{c}}$ ibnuhadiunj@gmail.com
}

\begin{abstract}
Unemployment Rate (UR) is an indicator for measuring the unemployment. Increase in the number of TPT in Indonesia by $1.84 \%$, this is due to the impact of the covid-19 pandemic. analysis to find out the factors that affect TPT in Indonesia is by using multiple linear regression. The results showed that the data contained heterokedasticity and spatial aspects. Spatial data analysis continued with the point approach is by the Geographically Weighted Regression method (GWR). GWR is a weighted regression that results in a model that is local. GWR modeling uses weighting kernels Fixed Gaussian, Adaptive Gaussian, Fixed Bi-Square, and Adaptive Bi-Square produces that GWR Adaptive Bi-Square better, review value of the R2,AIC and JKG. The ability of the GWR model explains the effect of UR on factors (Labor Force or economically active, Health Complaint and Poverty Percentage) by $89.1 \%$.
\end{abstract}

Keywords: Unemployment Rate(UR), Spatial Data, GWR, and Kernel Weight.

\begin{abstract}
Abstrak
Tingkat Pengangguran Terbuka (TPT) merupakan indikator untuk mengukur angka pengangguran. Peningkatan Angka TPT di Indonesia sebesar 1.84\%, demikian terjadi karena dampak dari pandemi Covid-19 di Indonesia. Analisis untuk mengetahui faktor yang mempengaruhi TPT di Indonesia yaitu dengan Regresi Linear Berganda. Pada hasilnya menunjukan bahwa data mengandung heterokedastisitas dan terdapat aspek spasial. Analisis data spasial dilanjutkan dengan Pendekatan titik yaitu metode Geographically Weighted Regression (GWR). GWR merupakan regresi terboboti sehingga menghasilkan model yang bersifat lokal. Pemodelan TPT dengan kernel pembobot Fixed Gaussian, Adaptive Gaussian, Fixed Bi-Square, dan Adaptive Bi-Square menghasilkan model GWR Adaptive Bi-Square yang terbaik. meninjau dari nilai $\mathrm{R}^{2}$, AIC dan JKG. Kemampuan model GWR dalam menjelaskan pengaruh TPT terhadap faktor-faktor (Angkatan kerja, Keluhan Kesehatan dan Persentase Kemiskinan) sebesar 89.1\%.
\end{abstract}

Kata kunci: TPT, Data Spasial, GWR, dan Pembobot Kernel.

\section{PENDAHULUAN}

Salah satu dampak yang dialami oleh beberapa negara saat pandemi corona yaitu sektor ketenagakerjaan, dimana selama pandemi banyak aktivitas diberhentikan sementara, pengurangan upah atau gaji, bahkan banyak juga pekerja yang terkena Pemutusan Hubungan Kerja (PHK). Hal ini menyebabkan Pencari Kerja Meningkat, Penyerapan Tenaga Kerja Yang Terbatas dan Angka Pengangguran Meningkat.

Untuk membuat suatu kesimpulan tentang suatu permasalahan maka cara preventif yang bisa 
dilakukan dengan memprediksi faktor-faktor yang mempengaruhinya. Salah satu analisis yang digunakan yaitu regresi linear berganda. Pada model regresi biasa dengan Regresi OLS Menghasilkan estimasi parameter yang sama pada semua wilayah, namun pada kenyataan kondisi data lokasi satu tidak sama dengan lokasi lainnya. Dengan demikian, asumsi kehomogenan sulit dipenuhi dimana data mengandung efek spasial (lokasi). Penelitian data spasial dengan menggunakan pendekatan titik yaitu Geographically Weighted Regression (GWR).

GWR merupakan metode statistik yang menggunakan informasi geografis dan menjadi bagian regresi terboboti. Kelebihan model GWR dibanding dengan regresi klasik menurut jurnal-jurnal terkait yaitu dapat memberikan model secara lokal. Terdapat empat kernel pembobot berbeda pada GWR yaitu fixed gaussian, adaptive gaussian, fixed bi-square dan adaptive bi-square, sehingga mampu menemukan kernel GWR terbaik pada model TPT.

\section{TINJAUAN PUSTAKA}

\section{Tingkat Pengangguran Terbuka}

Pengangguran merupakan istilah untuk seseorang yang tidak bekerja sama sekali, mencari pekerjaan, dan bekerja kurang dari dua kali seminggu. Menurut BPS (2021) Tingkat pengangguran terbuka adalah indikator yang digunakan dalam mengukur tenaga kerja yang tidak diserap oleh pasar kerja dan menggambarkan kurang termanfaatkannya pasokan tenaga kerja. Saat ini indonesia masih berada dalam masa bonus demografi. Memperbaiki dan meningkatkan kualitas pemuda di Indonesia adalah upaya yang sangat dibutuhkan dalam menghadapi angkatan kerja yang terus meningkat. Tingkat Pengangguran Terbuka (TPT) sebagai perbandingan banyaknya pengangguran terhadap banyaknya angkatan kerja. Diantara faktor yang mempengaruhi pengangguran yaitu angkatan kerja, keluhan kesehatan, dan persentase penduduk miskin.

\section{Regresi Linear Berganda}

Analisis regresi adalah metode umum untuk mendapatkan fungsi prediksi untuk memprediksi nilai variabel respon $Y$ menggunakan variabel prediktor $\left(x_{1}, \ldots, x_{k}\right)$. Regresi linear berganda digunakan untuk mendapati adanya pengaruh interaksi dua atau lebih variabel bebas terhadap variabel terikat. Berikut adalah model umum dari regresi linear berganda:

$$
Y=\beta_{0}+\beta_{1} X_{1}+\beta_{2} X_{2}+\cdots+\beta_{p} X_{p}+\varepsilon
$$

Jika penelitian menggunakan sebanyak $n$ pengamatan, model yang terbentuk adalah:

$$
Y_{i}=\beta_{0}+\sum_{k=1}^{p} \beta_{k} X_{i} k+\varepsilon_{i}
$$

dengan $i=1,2, \ldots, n$ pengamatan. bentuk di atas dapat juga disederhanakan dengan penulisan :

$$
Y=X \beta+\varepsilon
$$

$Y$ merupakan vektor $n x 1, X$ merupakan vektor $n x(k+1)$ dan $\hat{\beta}$ merupakan vektor $(k+1) x 1$.

Metode yang digunakan untuk mendapatkan paramater pada model di sini yaitu Ordinary Least Square $(O L S)$ atau biasa disebut metode kuadrat terkecil. Metode OLS dijalankan menggunakan nilai error kuadrat yang perhitungannya lebih mudah menggunakan matriks untuk menghitung taksiran kuadrat terkecil dari $\beta_{0}, \beta_{1}, \ldots, \beta_{k}$. Solusi dari OLS ini adalah

$$
\hat{\beta}=\left(X^{T} X\right)^{-1} X^{T} Y
$$

Terdapat empat tahapan uji yang harus dilakukan untuk memeriksa validnya suatu model yaitu Uji homokedastisitas, uji normalitas, uji multikolinearitas, dan uji autokorelasi.

Pengujian hipotesis yang paling penting dalam regresi salah satunya adalah uji F. Setidaknya terdapat variabel independen yang berpengaruh terhadap variabel dependen, sehingga uji $F$ untuk mengetahui bagaimanakah pengaruh semua variabel independen secara seluruh (simultan) terhadap 
variabel dependen. Statistik uji F yaitu :

$$
F_{\text {hit }}=\frac{\frac{J K R}{P}}{\frac{J K G}{n-p-1}}
$$

dimana :

$p=$ Banyaknya variabel bebas yang digunakan dalam penelitian

$\mathrm{JKR}=\hat{\beta}^{\prime} X^{\prime} y-n \bar{y}^{2}$

$\mathrm{JKG}=y^{\prime} y-\hat{\beta}^{\prime} X^{\prime} y$

$\mathrm{JKT}=\sum_{i=1}^{n}\left(y_{i}-\bar{y}\right)=y^{\prime} y-n \bar{y}^{2}$

Dengan kriteria pengambilan keputusan model Signifikan ketika $F_{\text {hitung }}>F_{\text {table }}$ dan kolom signifikansi yaitu sig< alpha (selang kepercayaan).

Uji parsial atau bisa dikenal dengan uji $\mathrm{T}$, fungsinya yaitu akan menguji pengaruh masing masing variabel independen terhadap variabel dependen. Statistik uji yang digunakan yaitu :

$t_{\text {hit }}=\frac{\widehat{\beta_{k}}}{S E_{\left(\widehat{\beta_{k}}\right)}}$

$S E_{\overline{\left(\beta_{k}\right)}}=\sqrt{C_{(p+1)} S}$

keterangan :

$\beta_{k}$ : Nilai koefisien pengamatan ke- $k ; k=0,1, \ldots, p$

$S E_{\left(\beta_{k}\right)}$ : Standar error koefisien pada pengamatan ke- $k ; \sqrt{C_{(p+1)} S}$ unsur ke $(p+1)$ diagonal $(x x)^{-1}$

$S$ : Akar dari kuadrat rata-rata galat

Kriteria pengambilan keputusan yaitu Tolak $H_{0}$ jika $t_{h i t}>t_{\left((n-p-1) ; \frac{\alpha}{2}\right)}$

dengan $\alpha$ atau taraf nyata $5 \%$

\section{Data Spasial}

Data yang mengandung unsur geografis dan menggunakan koordinat lintang dan bujur sebagai dasar referensi disebut data spasial. Data spasial memiliki dua bagain penting yaitu infomasi lokasi (spatial) dan informasi deskriptif (attribute). Pada penelian terhadap data spasial dibutuhkan konsen lebih karena menyelesaikan masalah berbasis lokasi sehingga memungkinkan terjadinya korelasi antar lokasi yang berdekatan. Pada data spasial adanya perbedaan kondisi wilayah, karena karakteristik lingkungan dan geografis memungkinkan terjadi heterogenitas spasial.

\section{Geographically Weighted Regression}

Geographically Weighted Regression merupakan metode regresi spasial dengan pendekatan titik yang berbasis wilayah. Model ini menghitung parameter atas setiap lokasi pengamatan atau dengan kata lain memperhitungkan lokasi data pengamatan (Ira 2016). Model GWR juga merupakan pengembangan regresi lokal dengan Ordinary Least Square $(O L S)$ menjadi regresi terboboti dengan Weighted Least Square (WLS) yang memperhatikan efek spasial. Nilai yang dihasilkan setiap Parameter berbeda-beda untuk setiap wilayah. Bentuk umum dari model GWR yaitu :

$$
Y_{i}=\beta_{0}\left(u_{i}, v_{i}\right)+\sum_{k=1}^{p} \beta_{k}\left(u_{i}, v_{i}\right) X_{i k}+\varepsilon_{i}
$$

keterangan :

$i=1, \ldots, n$

$Y_{i}=$ Variabel dependen lokasi ke $-i$

$\left(u_{i}, v_{i}\right)=$ Koordinat lintang bujur pada lokasi ke- $i$

$\beta_{0}\left(u_{i}, v_{i}\right)=$ Konstanta GWR 
$\beta_{k}\left(u_{i}, v_{i}\right)=$ Parameter atau koefisien regresi ke- $k$

$X_{i k}=$ Variabel prediktor ke- $k$ pada lokasi ke- $i$

$\varepsilon_{i}=$ Residual dengan asumsi $\varepsilon \sim \operatorname{IIDN}\left(0, \sigma^{2}\right)$.

(Fotheringham, Brunsdon, dan Charlton ,2002)

Metode yang digunakan untuk mengetahui penaksiran parameter di setiap model GWR yaitu metode Weighted Least Square (WLS), dimana setiap lokasi diberikan bobot yang berbeda sesuai dengan titik pengamatan dimana data tersebut diambil. Notasi pembobot yang digunakan pada setiap lokasi adalah $w_{j}\left(u_{i}, v_{i}\right)$ dengan $j=1,2, \ldots, n$ lokasi. Estimasi parameter GWR $\beta_{k}\left(u_{i}, v_{i}\right)$ untuk setiap variabel ke- $k$ pada lokasi pengamatan ke- $i$, sebagai berikut:

$$
\hat{\beta}\left(u_{i}, v_{i}\right)=\left[X^{T} W\left(u_{i}, v_{i}\right) X\right]^{-1} X^{T} W\left(u_{i}, v_{i}\right) Y
$$

Keterangan :

$$
\begin{aligned}
& \hat{\beta}\left(u_{i}, v_{i}\right)=\text { Parameter duga lokasi ke- } i \\
& X=\text { Matriks variabel prediktor berukuran } n x(p+1) \\
& W\left(u_{i}, v_{i}\right)=\text { Matriks bobot lokasi ke- } i \text { berukuran } n x n \\
& Y=\text { Vektor variabel respon berukuran } n x 1
\end{aligned}
$$

\section{Bandwidth GWR}

bandwidth diartikan sebagai radius dari titik lokasi pusat sebagai acuan dalam penentuan bobot setiap wilayah untuk model regresi. Ketika pengamatan masih dalam radius artinya model pada lokasi tersebut masih dianggap memiliki pengaruh, maka model dapat diberi bobot. Untuk menghindari heterogen dari varian, haruslah nilai bandwidth optimum. Menurut (Fortheringham dkk. 2002) terdapat beberapa metode penentuan bandwith optimum salah satunya yaitu metode Cross Validation (CV). Berikut persamaan CV secara matematis :

$$
C V=\sum_{i=1}^{n}\left[y_{i}-\hat{y}_{\neq i}(b)\right]^{2}
$$

dimana $\hat{y}_{\neq i}$ merupakan penduga $y_{i}$ dimana lokasi penngamatan $\left(u_{i}, v_{i}\right)$ dihilangkan dari proses estimasi guna mendapat radius yang optimal, sehingga mendapat $\mathrm{CV}$ minimum.

\section{Pembobot GWR}

Analisis model yang memperhatikan aspek spasial memerlukam pembobotan dalam perhitungannya.Hubungan kedekatan (neighboring) antarlokasi pengamatan dinyatakan dalam bentuk matriks pembobot $W_{i j}$ (Bekti 2012). Elemen pada matriks berisi $W_{i j}$ yang menyatakan kedekatan lokasi i dengan lokasi j. Jika bobotnya semakin besar maka lebih berpengaruh. Sedangkan pembobot dengan fungsi kernel mampu memberikan bandwidth optimum dimana nilainya sesuai dengan keadaan data. Terdapat empat jenis kernel pembobot diantaranya yaitu :

1. Fungsi Kernel Fixed Bi-Square

$$
W_{j}\left(u_{i}, v_{i}\right)= \begin{cases}\left(1-\left(\frac{d_{i j}}{b}\right)^{2}\right)^{2} & : \text { jika } d_{i j} \leq b \\ 0 & \text { :lainnya }\end{cases}
$$

dengan $W_{j}\left(u_{i}, v_{i}\right)$ merupakan matriks pembobot spasial untuk setiap lokasi, $d_{i j}$ sebagai jarak euclidean dan $\mathrm{b}$ adalah bandwidth yang sama untuk semua lokasi

2. Fungsi Kernel Adaptive Bi-Square

$$
W_{j}\left(u_{i}, v_{i}\right)= \begin{cases}\left(1-\left(\frac{d_{i j}}{b}\right)^{2}\right)^{2} & : \text { jika } d_{i j} \leq b \\ 0 & \text { :lainnya }\end{cases}
$$

dimana $W_{j}\left(u_{i}, v_{i}\right)$ merupakan matriks pembobot, $d_{i j}$ merupakan jarak euclidean. Jadi Fungsi kernel adaptif ini memiliki nilai bandwidth (b) yang berbeda untuk setiap titik lokasi pengamatan (Lutfiani, 2017). 
3. Fungsi Kernel Fixed Gaussian

$W_{j}\left(u_{i}, v_{i}\right)=\exp \left[-\frac{1}{2}\left(\frac{d_{i j}}{b}\right)^{2}\right]$

dimana $W_{j}\left(u_{i}, v_{i}\right)$ menyatakan sebagai matriks pembobot untuk fixed Gaussian, dan $d_{i j}$ adalah jarak euclidean dan $b$ merupakan bandwidth yang sama yang digunakan untuk setiap lokasi.

4. $\quad$ Fungsi Kernel Adaptive Gaussian $W_{j}\left(u_{i}, v_{i}\right)=\exp \left[-\frac{1}{2}\left(\frac{d_{i j}}{b_{i(q)}}\right)^{2}\right]$

dengan $W_{j}\left(u_{i}, v_{i}\right)$ merupakan matriks pembobot untuk setiap lokasi, $d_{i j}$ sebagai jarak antar lokasi pengamatan, dan $b_{i(q)}$ merupakan bandwidth adaptif atau berbeda untuk setiap titik lokasi.

\section{Pengujian Hipotesis}

1. Pengujian Kelayakan Model

$H_{0}: \beta_{k}\left(u_{i}, v_{i}\right)=\beta_{k}, k=1,2 . ., n$ (Tidak ada pengaruh faktor geografis pada model)

$H_{1}$ : Paling sedikit ada satu $\beta_{k}\left(u_{i}, v_{i}\right)$ yang berhubungan dengan lokasi $\left(u_{i}, v_{i}\right)$ (Terdapat pengaruh geografis)

$F_{\text {hit }}=\frac{\operatorname{SSE}\left(H_{0}\right) / d f 1}{\operatorname{SSE}\left(H_{1}\right) / d f 2}$

Dengan kriteria pengambilan keputusan apabila $F_{\text {hit }}>F_{\text {table }}\left(F_{(\alpha ; d f 1, d f 2)}\right)$ maka tolak $H_{0}$ dengan kata lain terdapat pengaruh geografis sehingga termasuk kedalam model yang layak atau kategori goodness of fit lebih baik dari regresi global.

2. Pengujian Paramater

$H_{0}: \beta_{k}\left(u_{i}, v_{i}\right)=0$ (Tidak ada pengaruh variabel bebas terhadap variabel respon)

$H_{1}: \beta_{k}\left(u_{i} \cdot v_{i}\right) \neq 0$ (Terdapat pengaruh signifikan antara variabel bebas terhadap respon)

$t_{\text {hit }}=\frac{\widehat{\beta}_{k}\left(u_{i}, v_{i}\right)}{\operatorname{SE}\left[\widehat{\beta}_{k}\left(u_{i}, v_{i}\right)\right]}$

kriteria pengambilan keputusan yaitu apabila $\left|t_{h i t}\right|>t_{\frac{\alpha}{2} ; d f_{2}}$ maka tolak $H_{0}$.

\section{Pemilihan model terbaik}

Penentuan model terbaik dapat ditentukan dari nilai $R^{2}$ terbesar dan nilai AIC yang terkecil.

1. Koefisien Determinasi $\left(R^{2}\right)$

$$
R^{2}=\frac{J K R}{J K T}=\frac{{\widehat{\beta_{k}}}^{T} X^{T} y-n \bar{y}^{2}}{\sum_{i=1}^{n}\left(y_{i}-\bar{y}\right)}
$$

Sedangkan dalam model GWR koefisien determinasi dapat ditentukan dengan persamaan berikut :

$$
R_{i}^{2}=\frac{J K T_{G W R}-J K S_{G W R}}{J K T_{G W R}}
$$

2. Akaike Information Criterion (AIC)

$$
A I C=2 n \ln (\sigma)+\ln (2 \pi)+n+\operatorname{tr}(s)
$$

\section{PEMBAHASAN}




\section{Deskripsi Data}

Pada penelitian analisis model Geographically Weightes Regression (GWR) di sini menggunakan 4 variabel yang terdiri dari satu variabel dependen yaitu Tingkat Pengangguran Terbuka (TPT) dan tiga variabel independen yaitu angkatan kerja (X1), keluhan kesehatan (X2) dan persentase penduduk miskin (X3). Gambaran umum mengenai informasi data disajikan dalam bentuk peta

1. Tingkat Pengangguran Terbuka (TPT)

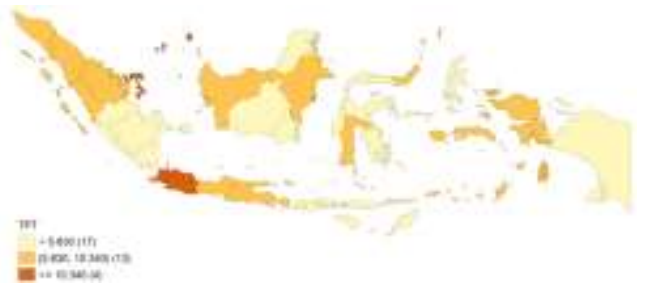

GAMBAR 1. Tingkat Pengangguran Terbuka

Dari peta Indonesia pada masalah pengangguran di Indonesia masih banyak titik wilayah yang memiliki warna cukup gelap artinya masih memiliki pengangguran dengan jumlah yang tak sedikit. Persentase tingkat pengangguran terbuka yang memiliki kategori sangat tinggi di Indonesia pada 2020 terdapat 4 provinsi yaitu provinsi DKI Jakarta, Banten, Jawa Barat dan Kepulauan Riau.

2. Angkatan Kerja

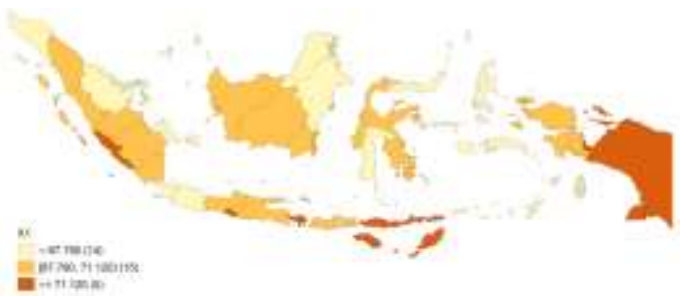

GAMBAR 2. Angkatan Kerja

Persentase Angkatan Kerja Tertinggi yang tergolong tinggi terdapat di 5 provinsi di Indonesia, mayoritasnya terletak pada beberapa provinsi di Nusa Tenggara, persentase tertinggi yaitu provinsi Bali dengan persentase $74.32 \%$

3. Keluhan Kesehatan

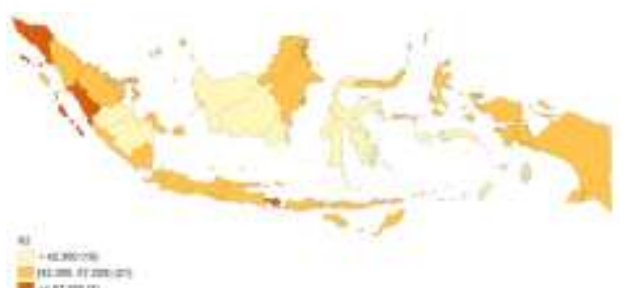

GAMBAR 3. Keluhan Kesehatan

Persentase Keluhan Kesehatan di Indonesia mayoritas berada di rata-rata yaitu sebanyak 21 provinsi di Indonesia. Namun masih beberapa yang memiliki persentase tinggi sebanyak 3 wilayah yaitu Bali, Aceh, dan Sumatera Barat dengan berturut-turut $61.32 \%$, 57.92\%, dan $57.25 \%$. 
4. Persentase kemiskinan

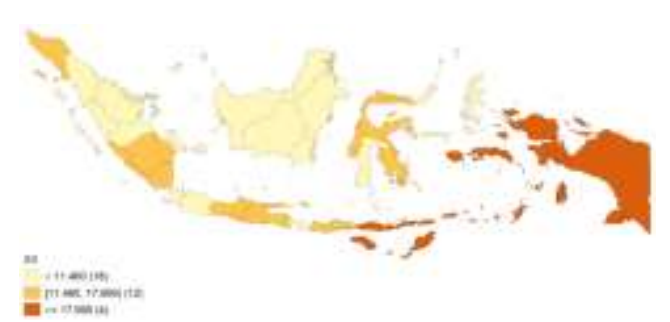

GAMBAR 4. Persentase Penduduk Miskin

Provinsi di Indonesia yang tergolong persentase penduduk miskin tertinggi yaitu terletak di Provinsi Papua, Papua Barat, Nusa Tenggara Timur dan Maluku dengan persentase berturutturut $26.8 \%, 21.7 \%, 21.21 \%$ dan $17.99 \%$. Penduduk miskin dengan kategori sedang terdapat 12 provinsi, sedangkan kategori rendah cukup banyak yaitu terdapat 18 provinsi dimana terendah terletak di Provinsi Bali dengan 4.45\%.

\section{Regresi Linear Berganda}

Model dapat dibentuk dalam persamaan regresi linear berganda, yaitu :

$$
Y=29.760-0.395 X 1+0.085 X 2-0.058 X 3
$$

Model diatas memiliki nilai $R^{2}$ sebesar 0.461 , artinya kemampuan model dalam menjelaskan pengaruh sebesar $46.1 \%$. Untuk mengetahui apakah model yang terbentuk benar memiliki pengaruh, maka terlebih dahulu dilakukan pengujian. Untuk mengetahui pengijuan model secara keseluruhan dengan menggunakan tabel Analisis of Variance (ANOVA) maka dapat diketahui nilai $F_{\text {hitung }}$.

TABEL 1. ANOVA

\begin{tabular}{lccccc}
\hline Sumber Variasi & DB & Jumlah Kuadrat & Kuadrat Total & $\boldsymbol{F}_{\text {hit }}$ & $\boldsymbol{F}_{\text {tabel }}$ \\
\hline Regresi & 3 & 61.522 & 20.507 & 8.544 & 2.92 \\
\hline Galat & 30 & 71.923 & 2.397 & & \\
\hline Total & 33 & 133.445 & & &
\end{tabular}

Berdasarkan hasil table $4.7 F_{\text {hit }}=8.554>F_{(0.05 ; 3 ; 30)}=2.92$ artinya setidaknya terdapat variabel independen yang memiliki pengaruh signifikan terhadap variabel TPT.

Pada hasil regresi global untuk mengukur validnya suatu model maka dilakukan uji asumsi klasik. Hasil Uji Asumsi Klasik memenuhi normalitas, multikolinearitas, dan autokorelasi . Namun tidak memenuhi homokedastisitas atau mengandung Heterokedastisitas. Ketika dilanjutkan dengan pengujian heterogenitas spasial dengan Breusch-pagan hasilnya terbukti mengandung heterogenitas spasial. Maka sesuai metode GWR penelitian dapat dilanjutkan pengujian spasial dan metode GWR dengan 4 pembobot kernel. Sehingga hasil dengan OLS nantinya mengandung presisi yang rendah disebabkan ketidakhomogenan ragam.

\section{Pemodelan Geographically Weighted Regression}

Ketika data mengandung heterogenitas spasial maka pemodelan dapat dilakukan dengan pendekatan titik yaitu dengan Geographically weighted Regression (GWR). Metode regresi spasial ini memang memiliki keunikan dimana model memerlukan pembobot dalam perhitungannya. Pembobotan pada model regresi dipengaruhi oleh bandwidth itu sendiri dengan sifat bandwidth yang adaptive dan fixed. Jenis dari pembobotan juga terbagi dua yaitu kernel Gaussian dan kernel Bi-square.

1. Fixed Bi-square

Bandwitdh yang digunakan pada fixed bisquare ini merupakan bandwidth yang sama untuk setiap lokasi pengamatan yaitu 16.38876. Estimasi parameter pada model GWR untuk setiap 
lokasi pengamatan yang berbeda-beda. Berikut nilai sebaran dari penduga parameter :

TABEL 2. Sebaran Estimasi Fixed Bi-square

\begin{tabular}{cccc}
\hline & Min & Median & Max \\
\hline Intercept & 19.690109 & 36.229741 & 50.309221 \\
\hline X1 & -0.725232 & -0.489966 & -0.061339 \\
\hline X2 & -0.325141 & 0.086031 & 0.145159 \\
\hline X3 & -0.184303 & -0.054546 & 0.199935 \\
\hline
\end{tabular}

Tabel 4.15 menunjukan bahwa penduga parameter dari angkatan kerja (X1) dan persentase penduduk miskin $(\mathrm{X} 3)$ bernilai negatif dengan masing- masing memiliki besaran pengaruh X1 sebesar -0.725232 sampai dengan -0.061339 dan pada X3 berkisar -0.184303 sampai 0.199935. Sedangkan pada variabel keluhan kesehatan memiliki nilai penduga yang negatif dan positif, dengan besaran pengaruh dari -0.184303 sampai 0.199935 .

Berikut sampel model GWR yang terbentuk dengan menggunakan pembobot kernel fixed bisquare :

$Y_{\text {Jakarta }}=49.20784+-0.71057268 X 1+0.13298866 X 2+-0.016613989 X 3$.

2. Adaptive Bi-Square

Pembobot pada adaptif bisquare memiliki langkah dan formulasi yang sama dengan fixed bisquare, namun memiliki perbedaan pada bandwidth dimana memiliki bandwidth sebanyak lokasi pengamatan. Berikut penulis sajikan nilai penduga parameter :

TABEL 3. Sebaran Estimasi Adaptive Bi-Square

\begin{tabular}{cccc}
\hline & Min & Median & Max \\
\hline Intercept & 15.319670 & 36.101383 & 89.437373 \\
\hline X1 & -1.398103 & -0.482105 & -0.188436 \\
\hline X2 & -0.049349 & 0.080284 & 0.206029 \\
\hline X3 & -0.266926 & -0.058491 & 0.468898
\end{tabular}

Nilai penduga parameter pada angkatan kerja maupun persentase miskin selalu bernilai negatif dengan besaran pengaruh masing masing berkisar - 1.398103 sampai -0.482105 dan -0.266926 sampai -0.058491. Sedangkan pada variabel keluhan kesehatan cukup bervariasi nilai penduga parameternya dari nilai negatif sampai positif, dengan besaran pengaruh sebesar -0.049349 sampai 0.080284.

Berikut sampel model GWR yang terbentuk dengan adaptive bi-square dari suatu provinsi :

$Y_{\text {Jakarta }}=87.30420+-1.3357518 X 1+0.13494970 X 2+0.42269128 X 3$

3. Fixed Gaussian

Pada kernel Gaussian fixed maka nilai bandwidth yang diperoleh hanya satu nilai yang optimum yaitu 5.334214. Estimasi parameter regresi untuk setiap wilayah, berikut nilai sebaran dari penduga parameter.

TABEL 4. Sebaran Estimasi Fixed Gaussian

\begin{tabular}{cccc}
\hline & Min & Median & Max \\
\hline Intercept & 19.78295 & 36.186340 & 56.425761 \\
\hline X1 & -0.823326 & -0.473132 & -0.210060 \\
\hline X2 & -0.149969 & 0.090014 & 0.149627 \\
\hline X3 & -0.193790 & -0.055773 & 0.200615 \\
\hline
\end{tabular}

Tabel menunjukkan bahwa variabel angkatan kerja (X1) memiliki koefisien yang selalu negatif dengan rentang -0.823326 sampai -0.210060 . Sementara pada koefisien keluhan kesehatan terdapat nilai negatif dan positif. Besarnya pengaruh keluhan kesehatan terhadap pengangguran terbuka sekitar interval -0.149969 sampai 0.149627. Hal ini terjadi juga pada koefisien persentase penduduk miskin bernilai negatif dan positif, dengan besar pengaruh berkisar -0.193790 sampai 0.2000615 .

Setiap lokasi menghasilkan model yang berbeda, berikut sampel model GWR pada suatu provinsi : 
Pemodelan Geographically Weighted Regression Menggunakan Pembobot Kernel Fixed dan Adaptive...

$Y_{\text {Jakarta }}=54.78055-0.7976142 X 1+0.132989749 X 2+0.026983833 X 3$.

4. Adaptive Gaussian

Pada kernel Adaptif Gaussian nilai bandwidth yang diperoleh hanya Sebanyak lokasi pengamatan yaitu dalam penelitian ini 34 . Berikut nilai sebaran dari penduga parameter :

TABEL 5. Sebaran Estimasi Adaptive Gaussian

\begin{tabular}{cccc}
\hline & Min & Median & Max \\
\hline Intercept & 19.320341 & 31.284880 & 82.539618 \\
\hline X1 & -1.268195 & -0.396746 & -0.239325 \\
\hline X2 & 0.023952 & 0.091884 & 0.152472 \\
\hline X3 & -0.174613 & -0.055882 & 0.369537 \\
\hline
\end{tabular}

Tabel di atas menunjukan bahwa variabel angkatan kerja (X1) memiliki koefisien regresi yang selalu negatif dengan rentang -1.268195 sampai -0.239325. Terjadi juga pada koefisien persentase penduduk miskin bernilai negatif, dengan besar pengaruh berkisar antara -0.174613 sampai -0.174613. Sementara kernel adaptif Gaussian pada koefisien keluhan kesehatan bernilai positif. Besarnya pengaruh keluhan kesehatan terhadap pengangguran terbuka sekitar interval 0.023952 sampai 0.152472 .

Berikut sampel model GWR yang terbentuk dari suatu provinsi :

$Y_{\text {Jakarta }}=71.66661+-1.0666241 X 1+0.12632881 X 2+0.205416864 X 3$.

\section{Uji hipotesis Model GWR}

Pengujian ini dilakukan untuk mengetahui apakah model layak dan mengandung faktor geografis pada model. Pengujian ini terbagi dua uji yaitu dengan uji F dan Uji T pada GWR. Pertama dilakukan uji F, berikut hasil uji untuk setiap pembobot :

TABEL 6. Uji Kelayakan Model

\begin{tabular}{|l|c|c|c|c|}
\hline Jenis Pembobot & $\boldsymbol{F}_{\text {hit }}$ & $\boldsymbol{F}_{\text {tabel }}$ & $\boldsymbol{P}$-Value & Kesimpulan \\
\hline Fixed Gaussian & 2.6929 & 2.107143 & 0.01477 & Tolak $H_{0}$ \\
\hline Adaptive Gaussian & 2.7185 & 2.107143282 & 0.01435 & Tolak $H_{0}$ \\
\hline Fixed Bi-square & 2.132 & 2.010248 & 0.03643 & Tolak $H_{0}$ \\
\hline Adaptive Bi-square & 4.9882 & 2.380334 & 0.001468 & Tolak $H_{0}$ \\
\hline
\end{tabular}

Berdasarkan table 6 semua pembobot menunjukan bahwa $F_{\text {hit }}>F_{\text {table }}$ maka $H_{0}$ ditolak artinya model-model yang dibentuk memiliki pengaruh geografis. Terdapat perbedaan signifikan antara model regresi global dengan model GWR pada penganalisisan menggunakan selang kepercayaan $95 \%$.

Berikut disajikan contoh hasil uji dengan dua kernel pembobot.

1. Fixed Gaussian

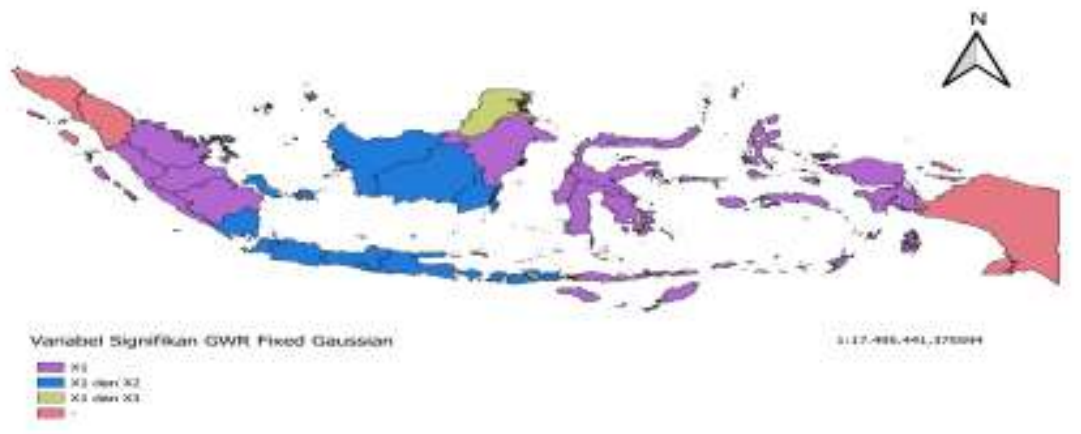

GAMBAR 5. Peta Kelompok Wilayah Berdasarkan Faktor yang Signifikan menggunakan Fixed Gaussian

Hasil parameter signifikan pada Fixed Gaussian terbagi menjadi 3 kelompok parameter. Terdapat 3 provinsi yang tidak memiliki pengaruh signifikan yaitu Aceh, Sumatera Utara, dan 
Papua. Sedikitnya variasi dari klasifikasi signifikan, menunjukan model GWR yang kurang identik dengan data spasial.

\section{Adaptive Bi-Square}

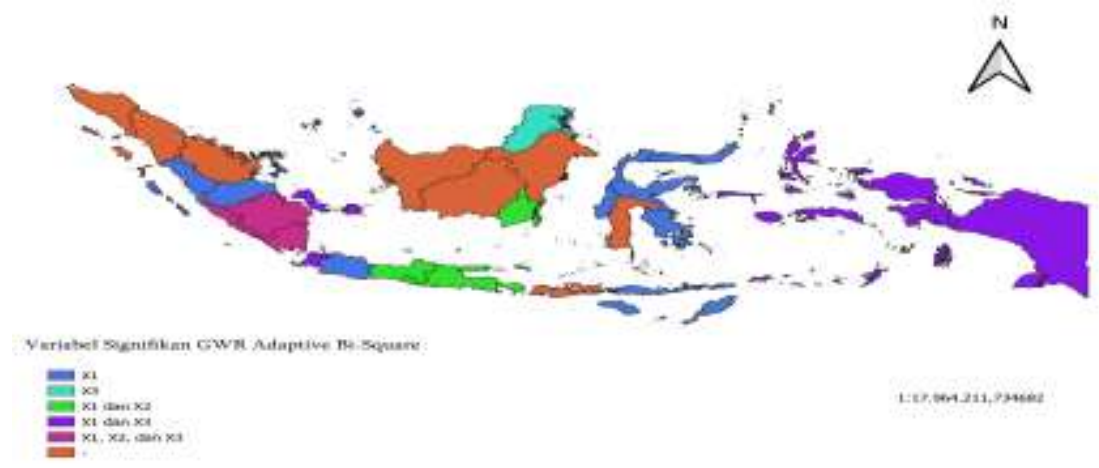

GAMBAR 6. Peta Kelompok Wilayah Berdasarkan Faktor yang Signifikan Menggunakan Adaptive Bi-Square

Variabel-variabel independen signifikan terhadap variabel TPT dengan adaptif bi-square terlihat bahwa model GWR terbagi ke dalam 5 kelompok sebaran model dan terdapat 8 provinsi yang tidak memiliki kesignifikanan. Jika dibandingkan dengan sebelumnya pada fixed gaussian, maka kelompok model signifikan adaptif bi square lebih bervariatif.

\section{Perbandingan Model GWR dengan Regresi Linear Berganda}

Metode untuk mengetahui model yang terbaik antara model regresi global dan regresi spasial dapat menggunakan nilai koefisien determinasi $\left(R^{2}\right)$ dan nilai Akaike Information Criterion (AIC). Hasil dari SSE/JKG bisa jadi pertimbangan juga dalam menentukan model terbaik. Penelitian ini terdiri dari 4 model GWR dengan pembobot berbeda dan 1 model regresi global.

\begin{tabular}{cccc}
\multicolumn{4}{c}{ TABEL 7. Nilai $\left(R^{2}\right)$, AIC dan JKG } \\
\hline Model & $\boldsymbol{R}^{\mathbf{2}}$ & AIC & JKG \\
\hline Regresi Linear Berganda & 0.461 & 131.9619 & 71.92322 \\
\hline Fixed Gaussian & 0.7998555 & 101.2162 & 26.70827 \\
\hline Adaptive Gaussian & 0.8017365 & 100.7926 & 26.45726 \\
\hline Fixed Bi-square & 0.7471976 & 106.9829 & 33.73520 \\
\hline Adaptive Bi-square & 0.8919505 & 84.61524 & 14.41866 \\
\hline
\end{tabular}

Dari Tabel 4.18 terlihat bahwa pemodelan tingkat pengangguran terbuka di Indonesia dengan metode GWR lebih baik dari regresi linear berganda, dimana nilai $R^{2}$ pada model GWR lebih besar. Nilai $R^{2}$ yang terkecil terdapat di model regresi linear berganda dan $R^{2}$ yang terbesar dimiliki model adaptif bi-square dengan 0.8919505. Artinya model dengan GWR adaptif bisquare mampu menjelaskan pengaruh tingkat pengangguran terbuka terhadap faktor-faktor nya sebesar $89.1 \%$ dan sisanya dijelaskan oleh faktor lainnya yang tidak terdapat pada penelitian ini. 
Pemodelan Geographically Weighted Regression Menggunakan Pembobot Kernel Fixed dan Adaptive...

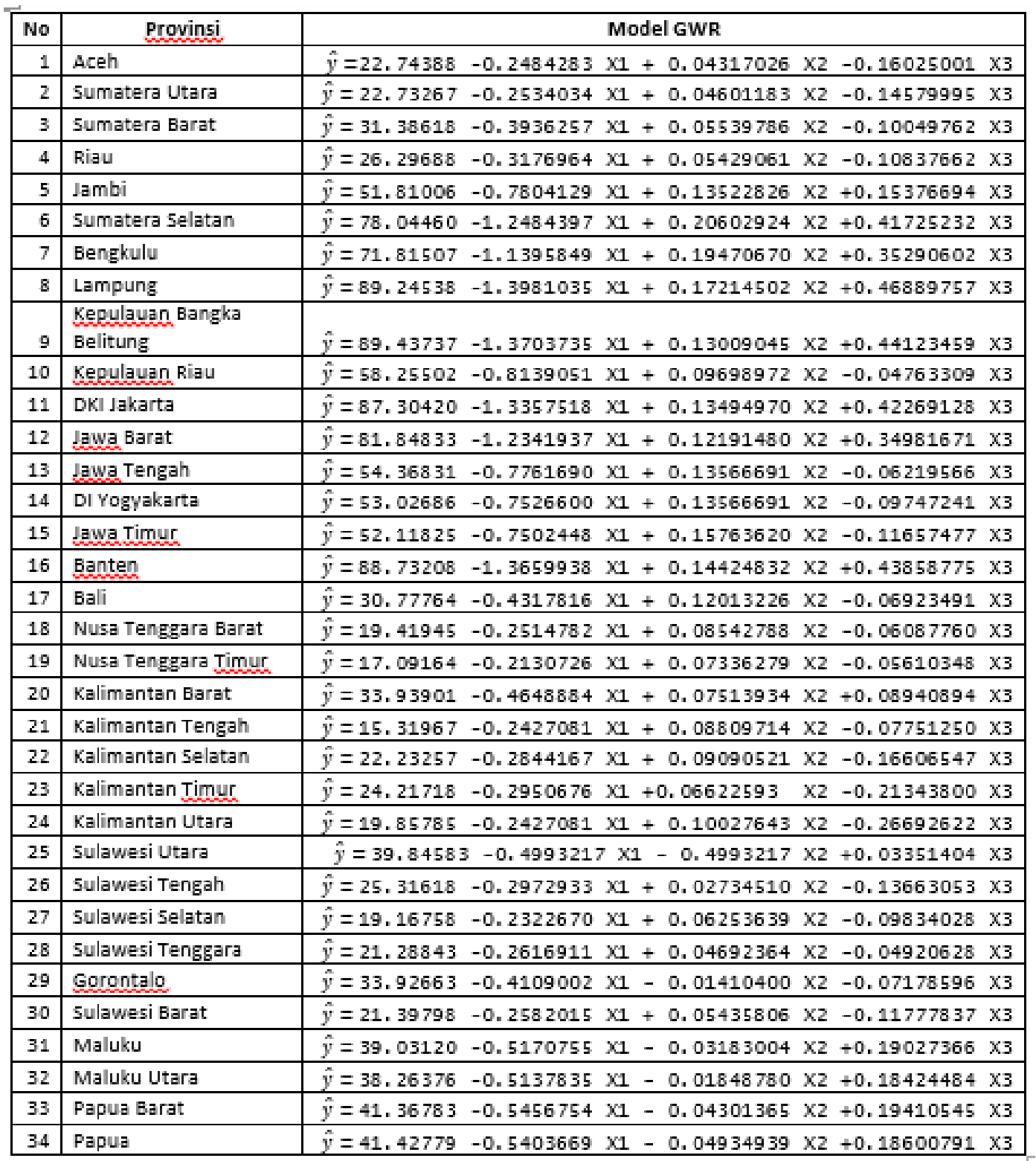

GAMBAR 7. Hasil Model GWR dengan Adaptive Bi-Square

\section{KESIMPULAN}

1. Model Regresi Linear Berganda yang dihasilkan pada kasus pengangguran terbuka :

$$
\widehat{Y}=29.760-0.395 X 1+0.085 X 2
$$

Memiliki 2 faktor signifikan (angkatan kerja dan Keluhan Kesehatan) dari 3 faktor. Hasil uji asumsi klasik menunjukkan bahwa model regresi global memenuhi asumsi normalitas, non multikolinearitas, dan non autokorelasi, sedangkan model tidak memenuhi asumsi kehomogenan.

2. Data yang digunakan merupakan data yang mengandung aspek spasial. Pengamatan menggunakan metode Geographically Weigted Regression menggunakan 4 pembobot berbeda yaitu Fixed Gaussian, Adaptive Gaussian, Fixed Bi-Square, dan Adaptive Bi-Square dimana menghasilkan kebaikan model yaitu memiliki pengaruh geografis menunjukkan perbedaan signifikan dengan regresi global.

3. Model dengan metode Geographically Weighted Regression adalah model terbaik dalam penelitian ini jika dibanding dengan Regresi linear berganda dengan metode OLS (Ordinary Least Square). Ditinjau dari nilai $R^{2}$, AIC dan Jumlah Kuadrat Galat (JKG) menunjukkan 
hasil GWR kernel Adaptive Bi-Square merupakan model terbaik.

\section{REFERENSI}

Badan Pusat Statistik. 2020. "Tenaga Kerja". Tersedia: https://www.bps.go.id/subject/6/tenagakerja.html. Diakses 26 Mei 2020.

Badan Pusat Statistik. 2021. Statistik Indonesia 2021. Jakarta:BPS.

Bekti, Rokhana Dwi 2012, 'Autokorelasi Spasial untuk Identifikasi Pola Hubungan Kemiskinan di Jawa Timur’, ComTech. vol. 3, No.1. 217-227.

Brundson C., Fotheringham, A.S., dan Charlton, M. E. 2002. Geographically Weighted Regression: The Analysis of Spatially Varying Relationship. England : John Wiley and Sons Ltd.

Caraka, Rezzy Eko dkk. 2017, "Geoggraphically Weighted Regression (GWR) Sebuah Pendekatan Regresi Geografis. Edisi Pertama. Cet.Ke-1. Yogyakarta : Mobius.

Ira, Farida. 2016. Model Geographically Weighted Regression $(G W R)$ dengan Pembobot Kernel BiSquare. Repository.upi.edu. 15-24.

Lutfiani, Nurul.dkk. 2019. Pemodelan Geographically Weighted Regression dengan Fungsi Pembobot Kernel Gaussian dan Bi-Square. Unnes Journal of Mathematics. 8(1). 82-91.

Nadya, Meila.dkk. 2017. Analisis Geographically Weighted Regression pada Kasus Pneumonia Balita di Jawa Barat. Jurnal Statistika dan Aplikasinya. Vol.1, No.1. 23-32. 